\title{
Fear and Fascination: Anti-Landscapes between Material Resistance and Material Transcendence
}

\author{
Werner Bigell
}

\begin{abstract}
This article examines the mechanisms that turn landscapes into anti-landscapes: projection, material interference, and ideological contradiction. Landscape and anti-landscape are dialectical twins; whereas landscape affirms cultural and aesthetic values, anti-landscape negates them through material resistance. This negation creates a sense of material transcendence, the aesthetic appeal through understanding that the world is larger than the projections onto it. Negation and material transcendence is the common denominator for anti-landscapes such as the exclusion zone around Chernobyl and the "feral houses" of the American suburb.
\end{abstract}

Keywords: “American Beauty”; Chernobyl; Ecotopia; Filatova, Elena; Lem, Stanislav; suburbia; Tarkowsky, Andrei; Zizek, Slavoj

\section{Introduction}

J. B. Jackson's statement that landscape is defined by the human presence in it appears to be anachronistic in an age of environmental awareness, with its fascination for the wild, yet it highlights the fact that meaning is not inherent in space but is projected onto it. Projection is a two-step process: when the Puritans came to America, they first projected the image of a New Israel onto space and then later sought to remake that space into the City upon the Hill. Landscape is the result of a cultural projection transforming physical space. Projection is not limited to humans; in his story "The Encantadas," Herman Melville describes how tortoises strug- 
gle incessantly against rocks in their path rather than going around them because of their "impulse to straightforwardness in a belittered world" (1856). The tortoises project straight lines onto their environment, and their projections transform the land, creating "deep ruts by ages and ages of the slow draggings." Projection is a biological mechanism transforming the environment, but only human beings transform space into landscapes, which are invested with cultural meaning through projections of a scientific, economic, aesthetic, political, or spiritual character.

Projection is preceded by representation. Representation can refer to the transfer of material and spatial patterns onto media such as maps, and it also refers to the formation of images of the external world in the mind. The aim of image formation is survival, not creating a mirror of the external world. Richard Dawkins describes the relation of image and reality from a biological viewpoint: "we animals inhabit a virtual world, constructed from elements that are, at successively higher levels, useful for representing the real world - which is exactly as it should be if our constrained virtual reality software is any good" $(1998,275)$. The linguist Stephen Pinker argues in a similar vein: "We are organisms, not angels, and our minds are organs, not pipelines to the truth. Our minds evolved by natural selection to solve problems that were life-and-death matters to our ancestors, not to commune with correctness" $(1997,561)$. Dawkins and Pinker argue against direct mental representation of the material world, but their stripe of constructivism allows a close functional relation of mind and matter because images are made for engagement in the world. Also the sociologist Norbert Elias (1986) describes a functional relation of mind and material world and distinguishes between external reality, knowledge, and the subject. Since knowledge is part of a survival strategy, it has to be "reality congruent." Humans are engaged in the material world and project mental images onto it, transferring cultural meaning onto space. Projection may alter a space materially or not, but it always alters the conception of it. A functional relation between representation, projection, and engagement also implies the possibility of incongruence and failure.

In society, mental images are projected onto the world not primarily for survival but as an expression of individual and collective engagement in the world. When this process fails, and the failure manifests itself in space, the result is dysfunctional, and quite likely an antilandscape. One can see projection failures as part of biological and 
cultural adaptation to the world, a call to not confuse image and material reality and to learn from failure to create a better image; negation here is a corrective, not a predicament. Incongruence and failure have an aesthetic component, as negation is a confirmation of materiality. In the act of touching there is limitation of movement. Yi-Fu Tuan states, "[t]ouch is the direct experience of resistance, the direct experience of the world as a system of resistance and pressures that persuade us of the existence of a reality independent of our imaginings" (1990, 8). Metaphorically speaking, the highlighted materiality of the anti-landscape is "touching," which is attractive for a culture that values authenticity. It is important to note the difference between this experienced-based and biological definition of the relationship of people to their surroundings with the classical definitions of landscape. Tim Cresswell argues that traditionally "[1]andscape is an intensely visual idea" and that "in most definitions of landscape the viewer is outside of it" $(2004,10)$. The dominance of the visual in landscape is caused by a class-bias (the material engagement of the farmer plays a lesser role than the visual consumption of the privileged visitor) as well as an idealist bias, valuing ideas more highly than direct contact with the material world. The negation in the encounter with the anti-landscape could be a vehicle to re-infuse a sense of materiality and limitation into our perception of landscape.

Negation presents itself in four different forms. First, there is the case where negative cultural meaning is projected onto landscape, such as the depiction of the desert in the Bible. Second, a cultural projection fails when it clashes with material reality. An example here is projection of the controllability of atomic power onto Chernobyl. Third, projections fail because the spaces they are projected onto are non-responsive. The Polish science-fiction author Stanislaw Lem creates worlds that remain radically other, showing that what seem to be "universal" human ideas are merely terrestrial in the universe. Fourth, projections can fail because of inherent ideological contradictions. An example is the American-style suburb, which negates both the city and countryside that it aims to reconcile. Yet paradoxically, all those failures can be appealing. Lem's non-responsive fictional worlds fascinate readers, the desert is a tourist destination, and "dark tourists" now explore both the exclusion zone of Chernobyl and the "feral houses" of abandoned suburbs. 


\section{The anti-landscape of negative projection}

Landscapes do not have to be physically altered in order to be meaningful. Whereas the Alps had been a dangerous obstacle for most of European history, romanticism reevaluated mountain ranges as havens of purity over the valleys of industrial corruption. Also deserts and wilderness areas have had shifting meanings projected onto them: the desert of Sinai is the prototypical anti-landscape, a testing ground for the people of Israel and a space to dispose unwanted elements: "But with many of them God was not well pleased: for they were overthrown in the wilderness" (1 Corinthians 10:5). The desert for Jesus was both a place of temptation by the devil and for reaffirming his belief: "And he withdrew himself into the wilderness and prayed" (Luke 5:16). Antilandscapes here are meaningful through negative projection but remain themselves unaltered.

Our age has turned many anti-landscapes into landscapes, but negativity lurks under the surface, as in the film "Deliverance" where a green landscape turns into an anti-landscape of horror. Often negativity is projected onto the city; the film "Taxi Driver" depicts New York as a place "where all the animals come out at night." Another trend in Western culture is to project ambivalent anti-landscapes onto the non-Western world. Anti-landscapes have migrated to the dangerous Orient (with its secret pleasures), claustrophobic and caste-ridden India (with its spirituality), the tropical heart of darkness (with its promise of promiscuity), or lawless Mexico (a place to party or to hide). Landscapes and anti-landscapes are dialectical twins, their opposition being fueled by the projection of contradictory desires.

\section{Non-responsive anti-landscapes}

The hidden worlds of the universe have been white screens for the projections of science fiction, but they can also be mirrors. In his novel Solaris, Stanislaw Lem illustrates the troubling possibility of an inhuman world. The planet Solaris is covered by an intelligent ocean as its sole inhabitant, but generations of researchers have only managed to describe phenomena on its surface in geocentric terms while failing to establish contact. Now interest in Solaris has subsided, and only one 
station is left in the planet's orbit. The three researchers there are challenged by a phenomenon that they are unable to report, for fear of being classified as mentally disturbed. The ocean creates apparitions of human beings, modeled on the memories of the researchers: it creates a mirror but remains itself incomprehensible. One of the researchers realizes that mirroring is at the center of their mission:

We take off into the cosmos, ready for anything: for solitude, for hardship, for exhaustion, death. Modesty forbids us to say so, but there are times when we think pretty well of ourselves. And yet, if we examine it more closely, our enthusiasm turns out to be all sham. We don't want to conquer the cosmos, we simply want to extend the boundaries of Earth to the frontiers of cosmos. For us, such and such a planet is as arid as the Sahara, another as frozen as the North Pole, yet another as lush as the Amazon basin. We are humanitarian and chivalrous; we don't want to enslave other races, we simply want to bequeath them our values and take over their heritage in exchange. We think of ourselves as the Knights of the Holy Contact. This is another lie. We are only seeking Man. We have no need for other worlds. We need mirrors. We don't know what to do with other worlds. A single world, our own, suffices us; but we can't accept it for what it is. We are searching for an ideal image of our own world [...] $(2003,75-76)$

The researchers remain caught in their human way of perception and try to rid themselves of the apparitions, unable to interpret them as contact to an intelligence that does not distinguish between self and other, past and present, idea and material reality. Many of Lem's fictional worlds portray anti-landscapes frustrating the human will to project a terrestrial "universal" onto the universe.

Anti-landscapes are spaces of material transcendence, where the limits of projection are manifest. They are suggestive of an underlying materiality. Edward Abbey saw the aesthetic potential in material transcendence when he described why he went into the desert:

Near the summit I found an arrow sign, three feet long, formed of stones and pointing off into the north, toward the those same old purple vistas, so grand, immense, and mysterious, of more canyons, more mesas and plateaus, more mountains, more cloud-dappled sunspangled leagues of desert sand and desert rock, under the same old wide and aching sky.

The arrow pointed into the north. But what was it pointing at? I looked at the sign closely and saw that those dark, desert-varnished stones had been in place for a long, long time; [...] I studied the scene with care, looking for an ancient Indian ruin, a significant cairn, perhaps an abandoned mine, a hidden treasure of some inconceivable wealth, the mother of all mother lodes ... But there was nothing out there. Nothing at all. Nothing but the desert. Nothing but the silent world. That's why. (1991, 21-22, Abbey's emphasis) 
Abbey does not invest the desert with negative or positive meaning but sees it as a non-responsive silent black screen pointing only at its materiality. The desert is appealing because it transcends projection and the aim of projection, usefulness: it is literally a wasteland. Slavoj Žižek discusses the aesthetic potential of waste: "[T]he properly aesthetic attitude of the radical ecologist is not that of admiring or longing for a pristine nature of virgin forests and clear sky, but rather that of accepting waste as such, of discovering the aesthetic potential of waste, of decay, of the inertia of rotten material which serves no purpose" $(2011,35)$. Anti-landscapes appeal because of their wastefulness, highlighting a materiality that serves no purpose.

Andrei Tarkovsky's film "Stalker" illustrates that the world appears to be non-responsive if one refuses to see it. The stalker guides two clients, a writer and a scientist, into the forbidden zone, to a place where wishes are fulfilled. The zone is an overgrown wasteland, full of deadly traps and industrial debris, and it is impossible to return the same way one came. For the Stalker the zone is home, whereas for the writer and the scientist it is only an obstacle for wish fulfillment. However, when they reach their destination, they are confused because they realize that their innermost wishes are anxiety-laden and elusive. They do not realize that the zone itself is a metaphor for life: it is dangerous, unidirectional, and wasteful. There is a spiritual tone in the film, but as Žižek points out, "for Tarkovsky, the very material process of corruption (decay, decomposition, rotting, inertia) is spiritual" and speaks of "Tarkovsky's spiritual materialism" $(2011,7)$. Whereas the visitors seek immaterial transcendence, the essence of the zone is waste. Waste is appealing because it escapes the utilitarian frames of modern civilization and of a romanticized nature where everything has a purpose in the web of life.

\section{The physical resistance of the anti-landscape}

Projection onto the material world involves abstraction. When constructing a house, predictions are made, based on abstractions about building materials, ground, climate, etc., and the projection may fail if there is an incongruence between abstraction and the material world. Scientific projection predicts the effects of the transformation of the material world but is limited by an increasing complexity, which reduces calculabil- 
ity. Whereas in an age of rapid industrial development and abundant resources the materiality of the world tended to be overlooked, the current environmental crisis is changing this, as Žižek argues: "[O]ver the last few decades, it has been fashionable to talk about the predominant role of 'intellectual labor' in our post-industrial societies - however, materiality is now reasserting itself with a vengeance in all its aspects, from the forthcoming struggles over scare resources (food, water, energy, minerals) to environmental pollution" $(2011,330)$.

The increasing control of the material world has lead to blindness towards material limits. Since industrialization has created large-scale projections, their failures have large-scale consequences. When cave dwellers dug a cave too wide, the collapsing roof may have killed a family, but when today earthquake and tsunami danger are miscalculated, the results can wipe out entire cities. Today the complexity of the material world is matched by a growing complexity of the social (including economic) world, also characterized by limitation of control. As Karl Marx observes: "A similar movement is going on before our own eyes. Modern bourgeois society, with its relations of production, of exchange and of property, a society that has conjured up such gigantic means of production and of exchange, is like the sorcerer who is no longer able to control the powers of the nether world whom he has called up by his spells" (1848). Today the powers of the nether world, social and productive forces, are accompanied by an increasing material incongruence, environmental and economic crises.

In his examination of the history of blackouts, David E. Nye shows that electrical light is a powerful sign of modern control, with the night being "treated as a canvas, which society may paint with lights" (2007, 77). Blackouts then can be seen as "a form of negation" revealing "an underlying disorder" $(2007,83)$. Hiding an underlying disorder can also be associated with natural light, as Paul Bowles shows in the novel The Sheltering Sky describing the blue desert sky: "the sky hides the night behind it, shelters the person beneath from the horror that lies above" (1990, 328). Material transcendence, evoking both fear and fascination, are associated with the absence of light. Electricity for light is produced in power plants, and when the projection of the behavior of the nuclear reaction in Chernobyl failed, it created a gigantic anti-landscape, an exclusion zone with uninhabited cities and villages. But if projection failed, the material world has not disappeared. Chernobyl today is a 
tourist destination, a prime example of "dark tourism," with several tour operators offering trips to the reactor and the abandoned city of Pripyat. In her online photo essays Elena Filatova explores the attraction of the exclusion zones in the Ukraine and Byelorussia. The city of Pripyat and the sarcophagus only form a small part of the vast contaminated area that Filatova calls the Land of Wolves. It is an exclusion zone in the Ukraine, and it is called the "Radiation Ecological Forest Reserve" in Byelorussia. According to Filatova (2005), new maps do not show the old roads, and places of human habitations, and this fact underscores the wasteland characteristic of the area. The area has a varied wildlife, wild boars, horses, and wolves. Vegetation is lush, engulfing the signs of former human presence. During evacuation cattle were slaughtered, but the offspring of cats live in the woods today (Filatova 2005). What is appealing about the exclusion zone is its material transcendence, the nuclear disaster pushing human beings away and allowing a glimpse into the underlying material world.

The Land of Wolves is also a memorial to human endeavor, visible in failure. Filatova sees the sarcophagus as modernity's lasting imprint on history: "The sarcophagus will remain radioactive for at least 100,000 years. The age for the pyramids of Egypt is 5,000 to 6,000 years. Each cultural epoch left something to humanity, something immortal, like Judaic epoch left us Bible, Greek culture - philosophy, Romans contributed law and we are leaving Sarcophagus, the construction that is going to outlive all other signs of our epoch and may last longer than the pyramids" (2005). How will the sarcophagus be viewed in the future? As a monument to ecological hubris? As a valiant effort to control nature that underestimated its material complexity? A monument to death, like the pyramids? Or a monument to creativity and risk-taking? Filatova is moved by the emptiness in a school: "There will be no more lessons in this school classroom, either. The only lesson taught here now is that the physical half-life of Americium-241, the daughter of Plutonium-241 is more than 400 years" (2005). Chernobyl teaches the lesson of possible large-scale incongruence between projection and materiality. How this incongruence is interpreted in a cultural context, however, is undetermined. The timelessness that Filatova describes means that the zone is removed from the human utilitarian clock and returned to geological time. In this sense the experience of the exclusion zone matches that of the desert, described by J. B. Jackson: "For what makes the landscape 
so impressive and beautiful is that it teaches no copybook moral, no ecological or social lesson. It simply tells us that there is another way of measuring time and that the present is, in fact, an enormous interval in which even the newest of man-made structures are contemporary with the primeval" $(1994,17)$.

The material transcendence of the zone evokes a paradoxical feeling of unreality, enhanced by its soundscape: "The silence is tremendous. No birds singing, no wind, nothing that can break this silence. Villages more picturesque than towns, houses and sheds do not look real. All look painted and I feel like I walk inside of this painting" (Filatova 2005). The sense of unreality is caused by the breakdown of projection, but there is no direct access to the material world. The underlying reality of radiation can only be perceived with a dosimeter; several photos in Filatova's essays show lush, pastoral greenery and a dosimeter in the foreground. A dosimeter is needed because radiation is distributed unevenly in the landscape. Aesthetics, usually limited to sensory perception, can incorporate scientific non-sensory data to make the invisible visible.

What is the lesson learned in the beautiful anti-landscape of the Land of Wolves? There is no fundamental difference between natural and human-made disasters, between whiteouts and blackouts. Both are limitations imposed by the material world. The anti-landscape is not a rejection of the human sphere, but a sign that human control over the world is limited. Limitation does not negate human endeavor but is its very essence, as there is no touch without material resistance. Throughout most of human history, the struggle with nature was the prerequisite for organization and solidarity. Only the blindness to material limitation has created an alienated hedonistic consumerism that forgot that civilization must be maintained in a struggle. Through industrialization the nature of this struggle has changed, as its main aim is not to subdue nature and to tame the whiteout but to avoid the negation of the material world, the blackout. This avoidance of negation and acceptance of limits could be the basis for a modern environmental awareness.

It might be argued that the anti-landscape suggests an updated epic sense of human endeavor. The epic theme has understandably been discarded by environmentalism (assuming that it is based on a struggle with nature with the aim to conquer it) and been supplanted by the notion of a harmonious nature into which humanity needs to integrate itself. However, both versions of human relation with nature, the heroic and 
the harmonious, are based on a false ideological premise, namely that nature is meaningful and predictable. A new epic sense of nature could stress the need to avoid negation through the material world as well as to accept that nature is wasteful and chaotic. Žižek argues that " " $[t]$ he world without us' is thus fantasy at its purest: witnessing the Earth itself regaining its pre-castrated state of innocence, before we humans spoiled it in our hubris. The irony is that the most obvious example is the catastrophe at Chernobyl: flourishing nature has taken over the disintegrating debris of the nearby city of Pripyat, which had to be abandoned" $(2011,80)$. There is no pre-lapsarian state of affairs, and the new epic quality in the relation to nature could be seen in learning to live with unpredictability, not in domination or projecting harmony onto the world.

\section{Suburbia: Anti-landscape of internal contradiction}

The suburb appears to be an unlikely candidate for being an anti-landscape, and Robert Fishman's definition of it does not conjure up images of toxic dumps: "The suburb must be large enough and homogenous enough to form a distinctive low density environment defined by the primacy of the single family house set in the greenery of an open, parklike setting" $(1987,5)$. However, as the Wall Street journalist Lee Siegel notices, the suburb is the screen for negative projections: "For Yates, Plath, Ginsberg and less gifted suburb-phobes [...], as well as hugely influential liberal sociologists and writers like David Riesman, William Whyte, Paul Goodman and Betty Friedan, it went without saying that the suburbs could transform the people who had committed the error of moving to them into the walking - make that driving - dead" (2008). Tuan makes a similar statement: "Among well-educated and sophisticated people, attitudes to suburban living are ambivalent: a professor of literature will admit to an address on the Greenacres with the same sheepishness that he admits to owning a color TV" $(1990,225)$. The suburb has an ambivalent role in Western (particularly American) society, embodying contradictory cultural desires. The reasons for the negative projection are complex: they originate both in an incongruence between material world and projections onto it and in an internal ideological contradiction in the projection itself. The suburb therefore is an anti-landscape that combines the hitherto discussed mechanisms of negation. 
The limits of material projections with regard to the suburb are well known. The suburb is built on the projection of unlimited energy for cars and unlimited space for development. The current discussions about peak oil, rising food prices (caused partially by conversion of agricultural land), and the financial crisis that has been caused by real estate speculation are beginning to show the limits of that projection. There are also economic reasons; suburbs in the Rust Belt are Fourierite communities being abandoned by a society that consumes but does not produce. Searching the Internet for "abandoned" and "suburb," one finds many images of deserted areas and overgrown houses (for example, DETROITURBEX.COM 2011). Christopher Leinberger argues that the suburbs may be the "next slum" because of a "major shift in the way many Americans want to live and work" (2008). Demographic changes such as the increasing number of single households, the older "empty nesters," as well as energy costs and the convenience of urban living are the driving forces, accompanied by the vicious circles of poor schooling and crime and a trend celebrating "Sex in the City" and deploring the suburban "Desperate Housewives" (the underlying reason here is economic segregation, the flight from the poor). Like the Land of Wolves, the anti-landscapes of abandoned suburban housing can be aesthetically appealing, as the photographer James D. Griffioen (2012) shows. His website contains many photos of vegetation taking over abandoned suburban "feral houses," and the reason for the aesthetic appeal is the physical resistance of the material world, creating material transcendence (in the case of Detroit, economic forces accompany material ones). As in Filatova's photos, the wasteland creates an epic sense of failure without providing a clear moral lesson. However, the suburb is more complex than Chernobyl because it not only is a monument of failed material projections but also of internal ideological contradictions. The same cultural ideals that the suburb embodies are felt to be betrayed by it. Here I will consider the ideals of a sense of place, of personal relations, of future-orientation, and of individualism.

The suburb negates a sense of place. It promises a closer relation to the land and a sense of place through individual land ownership. The earthiness of one's own garden is, however, contradicted not only by environmental unsustainability. According to James Howard Kunstler, the focus on land ownership means "the sacrifice of a sense of place: the idea that people and things exist in some sort of continuity, that we belong to the world physically and chronologically, and that we know where 
we are" $(1993,118)$. But the land, including its climate and economic activities, does not through its settlement patterns and land use create a sense of place. For the suburb is a projection of consumerism onto the land. Consumption overrides the material limits of an area, and it overrides local economies built on local resources. According to Fishman "the picturesque landscape has been carefully designed to represent the consumption of the property by the viewer/owner, and this passive enjoyment is precisely the relationship of suburbia to its environment" (1987, 49). This consumptive attitude leads to a perceived lack of authenticity and undermines a sense of place.

The suburb negates personal relations. Fishman calls the suburb a bourgeois utopia, a "vision of the modern family freed of the corruption of the city, restored to harmony with nature, endowed with wealth and independence yet protected by a close-knit, stable community" (1987, $\mathrm{x})$. One of its pillars is the separation of economic and private lives, a trend that started in London during industrialization. Suburbanites wanted to escape the moral temptations and corruptions of the city, to remove their families from the roughness of the economic world: "The bourgeois residence was now freed from traditional patterns to be redesigned as a wholly domestic environment - the home of a family that acted primarily as an emotional rather than an economic unit" (Fishman 1987, 9-10). Nevertheless, many writers present personal relations in the suburb as commodified. In Arthur Miller's Death of a Salesman, the family communicates in marketing speak; Linda advises Biff how to deal with his father:

And have a nice time with Dad. He may have big news too! ... That's right, a New York job. And be sweet to him tonight, dear. Be loving to him. Because he's only a little boat looking for a harbor. [she is trembling with sorrow and joy.] Oh, that's wonderful, Biff, you'll save his life. Thanks, darling. Just put your arms around him when he comes into the restaurant. Give him a smile. That's the boy ... $(2000,59)$

In Sam Mendes' film "American Beauty" Carolyn tells her husband to "act happy" when they go to a business reception, because the image of a good marriage is important for success. Betty Friedan describes the life of the suburban housewife as frustrating and lacking emotional fulfillment exactly because of the separation of the economic and the emotional spheres. What remains if both economic and emotional ties dissolve? In Mendes' film "Revolutionary Road" April reacts with "I 
don't feel anything" when her husband Frank confesses an affair, and Lester Burnham in "American Beauty" says that he feels "sedated." Karl Marx (1848) describes the effect of capitalist economic relations on personal ones: "The bourgeoisie has torn away from the family its sentimental veil, and has reduced the family relation to a mere money relation." The flight to the suburb accelerated this commodification of personal relations. Its lack of engagement in the (social and natural) environment that it embodies creates an effect of non-responsiveness, leaving the suburbanites, like Lem's space researchers or Tarkovsky's zone tourists, with mirrors, reflecting their own contradictory desires.

The suburb negates change and chance. Fishman points out that the suburb has to be understood in terms of its "rejected opposite," perceived as the "inhumane and immoral metropolis" $(1987,27)$. This flight was not an escape from the solvable problems of higher population density such as hygiene, but was a flight into a static world, away from modernity and its unpredictability. This sentiment is illustrated in the film "Revolutionary Road," where the dream of living an unpredictable life in Paris is pitched against the predictability of the suburb. The couple with the telling name "the Wheelers" gets stuck in suburbia when they trade in an exciting chance for material benefits. It is a paradox that "the economic system that created the suburb cannot provide stability and permanence" (Kunstler 1993, 170). "American Beauty" captures the dissonance between the timelessness of the suburb and a volatile job market that constantly evaluates "who is valuable and who is expendable." Rebecca Solnit discusses the design element of this suburban stasis: "The new architecture and urban design of segregation could be called Calvinist: they reflect a desire to live in a world of predestination rather than chance, to strip the world of its wide-open possibilities and replace them with freedom of choice in the marketplace" (Solnit 2001, 255). The timelessness of the suburb matches that of the Land of Wolves or of the abandoned suburbs of the Rust Belt. The suburb is both a utopia, escaping the upheavals of the industrial age, and a dystopia, generating a feeling of being frozen in time. An interesting moment is the transition from utopia to dystopia, seen for example in "American Beauty" where the utopian dream is pinched by material transcendence, the foreshadowing of doom; we see vegetation highly controlled in the film (e.g. obsessive pruning), but seeing it today, one cannot suppress images of trees breaking through floors in feral houses or in Pripyat. 
The suburb negates individualism and privacy. Kunstler points out that there has been a discourse on conformity in the suburb since the 1950s (1993, 183), the fear of being a "dime a dozen." In "Revolutionary Road" there is a haunting image of office worker clones exiting the commuter train, and "A Serious Man" shows a horizon of sameness, of identical houses. The suburb has become a symbol for the fact that individualism in advanced capitalism is reduced to consumer choice. This includes the former cultural battleground of sexual identity. "American Beauty" ironically portrays a lesbian couple with identical haircuts and blurs the features of the gay neighbors of the Burnhams into exchangeable lawyer types, presenting themselves as "partners" and eliciting the question from their army neighbor: "What are you guys selling?" The disappearance of individualism has economic roots, as Michael Hardt points out: "[T]he production of the refrigerator and the automobile are only midpoints for the creation of the labor and gender relations of the nuclear family around the refrigerator and the mass society of individuals isolated together in their cars on the freeway" $(2010,142)$. Capitalism is based on individualism but also undermines it, as individuals are first transformed from producers into consumers and then, as for example by Google and Facebook, from consumers to the raw data material being sold to advertisers. Kunstler points out that the "extreme individualism of property ownership [...] tends to degrade the idea of the public realm" $(1993,26-27)$, and it is this lack of public space that paradoxically undermines privacy. Jackson argues that the suburb answers the "persistent need for privacy" through providing a "freestanding dwelling on its own well-defined plot of land" (1994, 157), but privacy conflicts with property, with the lack of public space. The suburb resembles a panopticon, and it is in this sense different from both the city and nature, where one can hide or be anonymous. The uncontrolled spaces in the suburb, however, are few and prone to invasion. In "American Beauty," Carolyn's affair ends when she is seen with her lover, Lester smokes a joint with Ricky but is soon found by his wife, and Ricky must keep his door unlocked. Ricky's camera, with which he records his neighbors, is a symbol for this pervasive visibility. The projection of freedom onto space has led to social control. This is not surprising because the idea of generating freedom through ownership is based on control of space, not on the openness of space. 


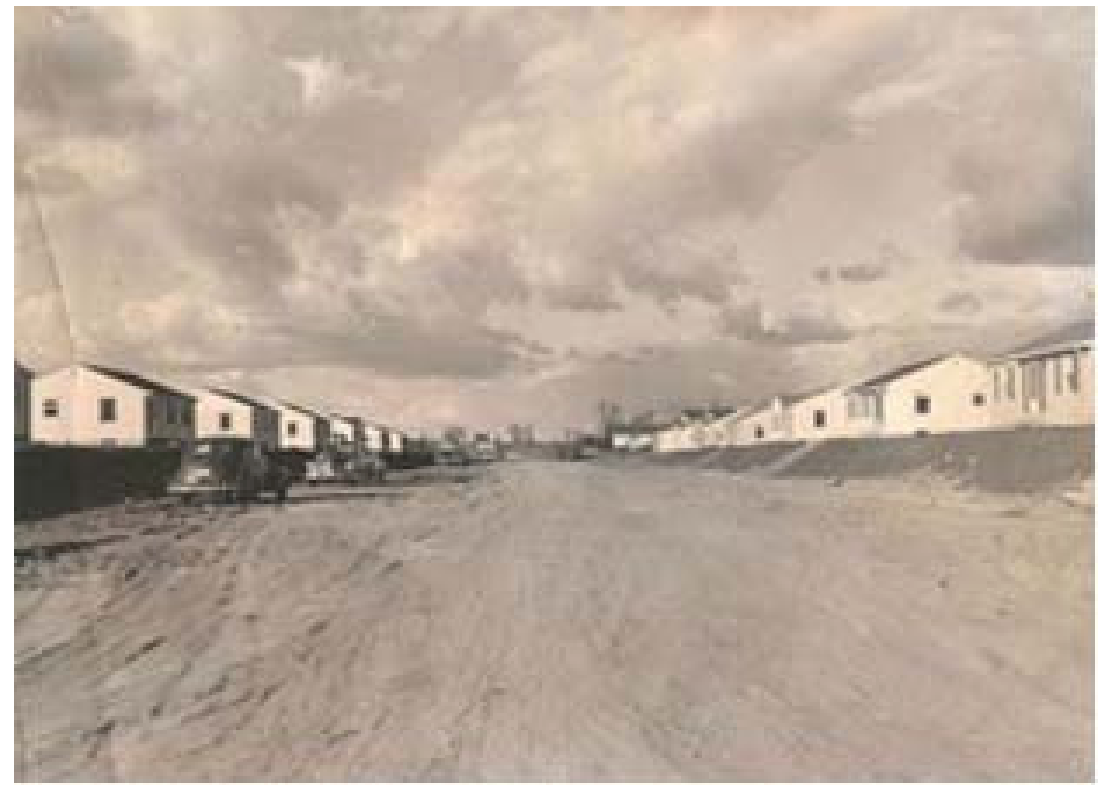

Illustration 1. Richfield Minnesota, 1950. Richfield Historical Society / Wikimedia Commons

The suburb negates verticality. The reduction of social dimensions in the suburb is mirrored by two-dimensionality in real space. Horizontality is not the same as being close to the ground. The historical rootlessness of the suburb and its environmental unsustainability negate the earth, and its anti-modern attitude negates reaching out into the sky. It creates a feeling of simultaneous agoraphobia and claustrophobia, of two-dimensional infinity, of being stuck in endless space. Moving through this space on wide roads means "getting nowhere fast."

The suburb negates the past and the future. It appears to emulate smalltown life but negates both traditional and modern lifestyles. Kunstler sees the prevalent DIY-culture as a negation of local economic relations and workmanship $(1993,171)$ and blames the modernist rejection of the past for the homogenized suburbs. But this view is too narrow: the suburb negates not only the past but also the future. The individualism of the suburb exclusively accommodates the nuclear family, excluding collective models of living found among some religious groups such as the Amish, the Amana Community, the Shakers, the Hutterites, or the 
Jewish kibbutz. Suburbia is equally hostile to secular experimentation of the sort that first emerged in the nineteenth century at the Brook Farm, Fruitlands, and the Fourierite communities, and which re-emerged in the land communes of the 1960s. Suburbia can also be seen as a bastion against the open relationships advocated by the communist Sexpol movement of the interwar era, as well as the architectural avant-garde of the early Soviet years: the Byt-movement advocated communal living and began constructing buildings that facilitated communal eating and child rearing. Stalin soon denounced this movement as "leftist utopianism" (Hatherley, 2008, 54) and abandoned social experimentation. Both consumer capitalism and Stalinism negate collective alternatives, leading to what Owen Hatherley calls a "degeneration of the sexual-utopian imagery" $(2008,85)$.

A voice from a more future-oriented age is Ernest Callenbach's unabashedly utopian novel Ecotopia. Cities in Ecotopia have shed their suburban areas. The cover of the book illustrates the ideal of densely settled areas set in vast natural spaces. Likewise, public transport replaces automobile traffic in Ecotopia. Callenbach recycles the Aristotelian city ideal, arguing that settlements should be "microcities," consisting of some tens of thousands inhabitants, a short distance from a train station. $\mathrm{He}$ proposes to make economic activity the center of life, thus re-introducing a sense of engagement in the world, and to replace core families with collective living arrangements. Callenbach's novel is not a recipe for a pastoral return to a golden age but a bold imagination of creating a better collective future with modern means. Today the term "utopia" is negatively charged, referring to failed social experiments. However, we do not live in a post-utopian age, as Žižek points out, but the negation of utopia is itself utopian: "The true utopia is the belief that the existing global system can reproduce itself indefinitely; the only way to be truly 'realistic' is to think what, within the coordinates of this system, cannot but appear as impossible" $(2011,363)$. Today the "rejected opposite" of suburbia is not the gentrified industrial city but the blocks of collective housing found for example in the former Soviet Union. Many Westerners look at them with horror, the remnants of a failed dream, anti-landscapes of ideological meltdowns. But are they failures? The rejection of socialist housing is not so much based on its aesthetic uniformity but on a rejection of the underlying utopian vision of an egalitarian society. This is the Soviet version of the City upon a Hill. 


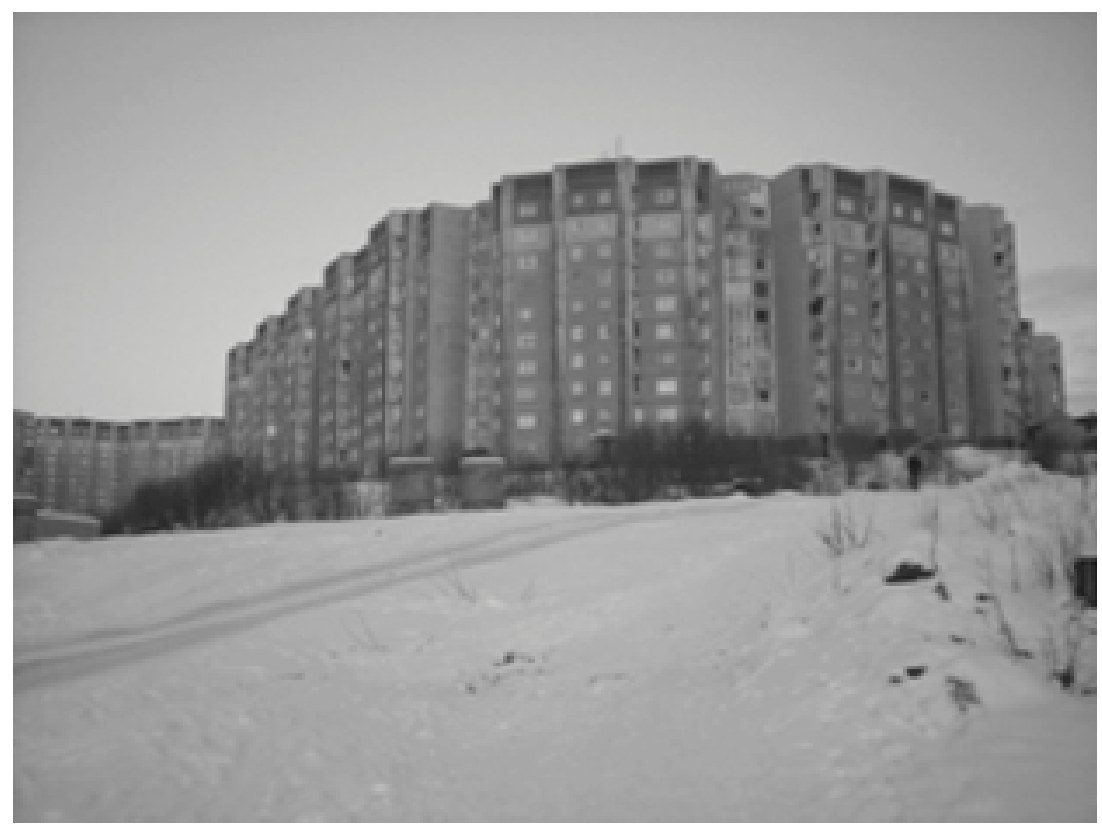

Illustration 2. Murmansk, Russia 2010, photograph taken by the author

This image depicts part of a large housing area. Its castle-like vertical appearance appears intimidating but is an adaptation to the arctic climate. The harsh winds in Murmansk are not felt in the space inside the "castle" where children can play. There is also recreational space around the buildings, and the area is within walking distance of the city center and connected by public transportation. If one sees equality and community rather than individualism as guiding principles of housing, then the anti-landscape character of these blocks disappears. Also, those blocks are not a remnant of the past. New houses in Russia look similar to the old ones. The suburban mind is prone to see collective housing as an anti-landscape, but this gaze is reciprocated: from a collectivist utopian perspective, the suburb is an anti-landscape of capitalist "there is no alternative" fatalism. Even though there are Western-style suburbs in Russia today for the very rich, mostly the term suburb refers to substandard, often wooden, houses on the periphery for the disadvantaged classes, showing that cultural coordinates create the ideal of the suburb as well as anti-landscapes. 


\section{Conclusion}

Landscape and anti-landscape are dialectical twins. Whereas landscapes can be protected, anti-landscapes are perceived as failures. The pastoral countryside, however, cannot be fully understood without the background of its rejected others, the desert or the dump. What is a landscape and what is an anti-landscape depends on the cultural lens of the viewer. Both landscape and anti-landscape have their origin in the interaction of the tangible material and the intangible cultural world. Anti-landscapes originate in cultural projection as well as in material transcendence, experienced as an unresponsive mirror or in the incongruence between projection and material reality. In addition there is the possibility that the projection of cultural meaning onto landscape is in itself incongruent or contradictory, and this is experienced by the visitors in Tarkovsky's zone as well as by suburbanites who feel that their projection of the ideas of individualism, freedom, nature, etc. are betrayed.

The anti-landscape highlights the "touching" aspect of landscape, the elements of limitation, negation, and failure that accompany human engagement in the world. This "touch" can be experienced with fear, as limit and failure, or with fascination, as material transcendence, suggesting a world behind projection. Since human engagement in the world is always prone to failure, anti-landscapes are common, and they are not moral predicaments but can engender a new epic sense of relating to the environment, of living with unpredictability. Material negation can never be overcome since the world is not ordered as our projections of it, but wasteful. Electricity and the sun do not make the night disappear; blackouts can suddenly switch off visual control, and also in a whiteout one experiences the disappearance of the horizon, confusing the sense of gravity. Both are disturbing because they remove control, but also exhilarating because they link us to the material world. 


\section{Bibliography}

Abbey, Edward. 1991. The Journey Home. New York: Plume.

Bowles, Paul. 1990. The Sheltering Sky. New York: Vintage.

Callenbach, Ernest. 1990. Ecotopia. New York: Bantam Books.

Coen, Ethan and Joel Coen. 2009. "A Serious Man” (DVD). United Home Entertainment.

Cresswell, Tim. 2004. Place: a short introduction. Oxford: Blackwell Publishing.

Dawkins, Richard. 1998. Unweaving the Rainbow: Science, Delusion and the Appetite for Wonder. Boston: Houghton Mifflin Company.

DETROITURBEX.COM. 2011. "Abandoned Neighborhood in Highland Park.” Available on-line at: http://detroiturbex.com/content/neighborhoods/hpdead/hpdead.html (last access April 4, 2011).

Elias, Norbert. 1986. "Über die Natur.” Stuttgart: Merkur 40, 469-487.

Filatova, Elena. 2005. "Ghost Town and Land of the Wolves: Travelogue 2003-2005." Available on-line at: http://www.elenafilatova.com/ (last access March 19, 2011).

Fishman, Robert. 1987. Bourgeois Utopias: The Rise and Fall of Suburbia. N.p.: Basic Books.

Griffioen, James D. 2012. "Feral Houses" (photograph collection). Available on-line at: http://www.jamesgriffioen.net/index.php?/prairies/feral-houses/ (last access June $30,2012)$.

Hardt, Michael. 2010. "The Common in Communism". In Douzinas, Costas and Slavoj Žižek (eds.). The Idea of Communism. London: Verso.

Hatherley, Owen. 2008. Militant Modernism. Winchester and Washington: Zero Books. Jackson, John Brinckerhoff. 1994. A Sense of Place, a Sense of Time. New Haven: Yale UP.

King James Bible. 1769. Available on-line at: http://www.kingjamesbibleonline.org/ (last access March 5, 2011).

Kunstler, James Howard. 1993. The Geography of Nowhere: The Rise and Decline of America's Man-Made Landscape. New York: Touchstone.

Leinberger, Christopher B. 2008. "The Next Slum? The subprime crisis is just the tip of the iceberg. Fundamental changes in American life may turn today's McMansions into tomorrow's tenements." The Atlantic, March 2008. Available on-line at: http:// www.theatlantic.com/magazine/print/2008/03/the-next-slum/6653/ (last access November 20, 2011).

Lem, Stanislaw. 2003. Solaris. London: Faber and Faber.

Marx, Karl. 1848. Manifesto of the Communist Party. Available on-line at: http://www. marxists.org/archive/marx/works/1848/communist-manifesto/ch01.htm\#007 (last access April 2, 2011).

Melville, Herman. 1856. "The Encantadas or Enchanted Islands." Available on-line at: http://www.melville.org/encant.htm (last access March 5, 2011).

Mendes, Sam (director). 1999. "American Beauty” (DVD). Dreamwork Productions.

Mendes, Sam. 2008. "Revolutionary Road" (DVD). Dreamwork Productions.

Miller, Arthur. 2000. Death of a Salesman. London: Penguin.

Nye, David E. 2007. "Are Blackouts Landscapes?” American Studies in Scandinavia, 39:2, 2007, pp. 72-84. 
Pinker, Stephen. 1997. How the Mind Works. New York: Norton.

Richfield Historical Society. 1950. "Photo showing Suburban development on Washburn Avenue, Richfield, Minnesota." Original photo in the collections of the Richfield Historical Society. Available on-line at: http://commons.wikimedia.org/wiki/ File:Richfield_MN-washburn_Ave.jpg (last access November 23, 2011).

Siegel, Lee. 2008. "Why Does Hollywood Hate the Suburbs? America's long artistic tradition of claiming spiritual death by station wagon" in The Wall Street Journal, December 27, 2008. Available on-line at: http://online.wsj.com/article/ SB123033369595836301.html (last access March 30, 2011).

Solnit, Rebecca. 2001. Wanderlust: A History of Walking. London: Verso.

Tarkovsky, Andrei (director). 2002. "Stalker" (DVD). Artificial Eye.

Tuan, Yi-Fu. 1990. Topophilia: A Study of Environmental Perception, Attitudes, and Values. New York: Columbia University Press.

Žižek, Slavoj. 2011. Living in the End Times. London: Verso. 